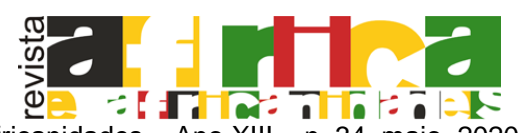

Revista África e Africanidades - Ano XIII - n. 34, maio. 2020 - ISSN 1983-2354

www.africaeafricanidades.com.br

ARTIGO

\title{
O deslugar do imigrante nacional em Moçambique no romance Neighbours, de Lília Momplé
}

Nilza Gomes de Oliveira Laice ${ }^{1}$

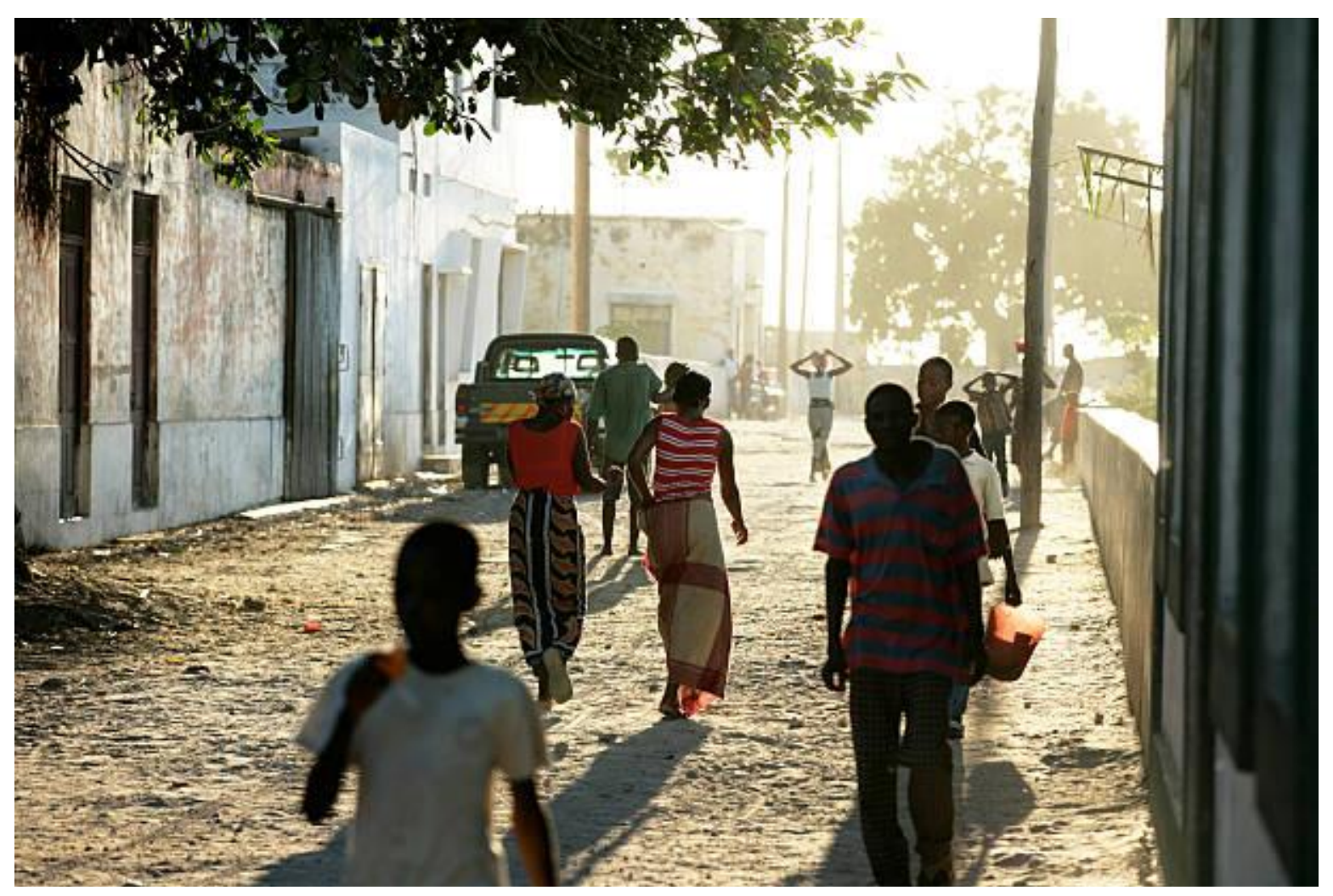

RESUMO: $O$ artigo pretende discutir as condições sociopolíticas que estavam sujeitos os imigrantes nacionais moçambicanos durante a guerra civil, a partir do romance Neighbours de Lília Momplé. O estudo tem como base o pensamento de Julia Kristeva sobre o ser estrangeiro em nós mesmos e a discussão de Édouard Glissant em volta de uma poética da diversidade, a fim de dessepultar e compreender as tragédias domésticas perpetuadas sob o jugo do Apartheid em Moçambique.

PALAVRAS CHAVES: imigrante nacional; defeito de alteridade; apartheid.

${ }^{1}$ Doutoranda/UnB - E-mail: nilza.laice@gmail.com 


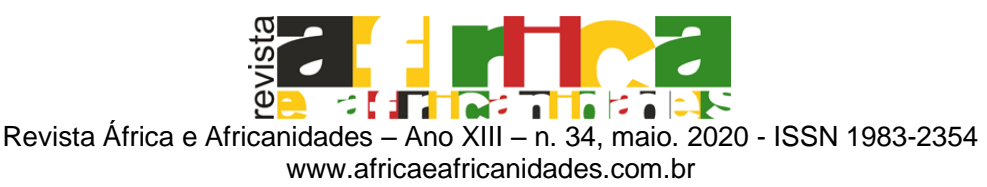

www.africaeafricanidades.com.br

\section{Introdução}

A expressão imigrante nacional pode causar irritação, estranhamento ou, simplesmente pena pelo desconhecimento que a autora tem do termo migração. Entretanto, o que se propõe neste estudo é pensar na figura do indivíduo, que sai de uma província para outra e desperta no seu conterrâneo, irritação, estranhamento e muitas vezes pena, tornando-o estrangeiro na sua própria terra, como aponta Julia Kristeva:

Estrangeiro é todo aquele que não nasceu em nosso país, não vive em nossa cidade, não fala nosso idioma, não conhece nossos costumes e comporta-se de modo sempre tao... estranho! Simples assim? Nem tanto. Estrangeiro também é aquele vizinho calado, aquele que não frequenta a mesma igreja, o que não é do nosso partido, nosso time, grupo, turma, tribo, não importa. Estrangeiro é qualquer um diferente de nos mesmos, ou seja: o outro (KRISTEVA, 1994, ?).

Destarte, o estrangeiro neste trabalho ${ }^{2}$ será denominado: imigrante nacional ${ }^{3}$, aquele que se movimenta dentro do seu país e é designado o outro, o que não tem lugar naquele espaço, também apelidado viente (aquele que veio). É alguém que pela condição de desterrado que lhe é atribuída, precisa provar para aos demais que merece estar naquele lugar, nessa "nova terra".

A partir daí pretende-se descrever neste estudo as condições sociopolíticas que estavam sujeitos os imigrantes nacionais moçambicanos durante a guerra civil, tendo como objeto o romance Neighbours, de Lília Momplé, de forma a perceber como viviam esses imigrantes que não tinham e não tem lugar no seu próprio País. Para tal, a metodologia de análise aqui adotada, baseia-se em duas principais perspectivas teóricas, quais sejam: Julia Kristeva sobre o ser estrangeiro em nos mesmos e na discussão de Édouard Glissant em volta de uma poética da diversidade, possibilitando encontrar um caminho que melhor facilite 0 diálogo entre a imigração e alteridade, caminho este que pode ser permeado a partir do conceito de crioulização desenvolvido por Glissant.

No romance Neighbours, baseado em fatos reais a autora conta em 24 horas, quase que obedecendo às três unidades Aristotélicas (tempo, espaço e acção), o que não acontece necessariamente porque o olhar "curioso" do narrador se desloca para três apartamentos e faz o relato do que vê, não de uma forma linear, mas de forma fragmentada entre os três tempos verbais. E narra a trama de três famílias desconhecidas ligadas inteiramente pelo jugo do Apartheid ${ }^{4}$ em

\footnotetext{
2 Este artigo surgiu como trabalho final da disciplina Representações do outro, durante a qual fuime indagando sobre a possibilidade de existência de imigrantes nacionais na obra de Lília Momplé, corpus literário de minha tese, ainda em andamento.

3 Imigrante nacional: conceito que estou desenvolvendo na minha Tese, pensando na ideia do sujeito nacional que se sente desterrado e marginalizado na sua própria terra.

${ }^{4}$ Apartheid significa em afrikans, separação ou segregação. Foi uma política de desestabilização e segregação racial, que surgiu e vigorou oficialmente na Ảfrica do Sul entre 1948 a 1990.
} 


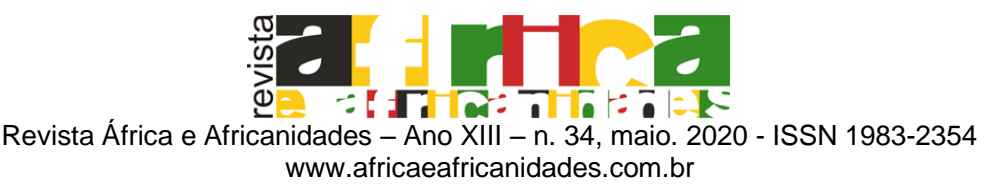

Moçambique, convidando-nos a refletir sobre as tragédias domésticas ocorridas no período da guerra civil.

A figura do imigrante nacional é nos introduzida logo no início da narrativa através de Muntaz, mulher e jovem que pretende continuar os seus estudos e se tornar médica. Entretanto, como não existia uma universidade em Nampula (sua cidade), a personagem precisa se deslocar à Maputo e sujeitar-se a condição de imigrante nacional, associada ao fato de ser mulher estudando medicina, o que há faz imigrante nacional duas vezes. A estudante de medicina faz um movimento quase heróico para sua época pois como afirma Sueli Carneiro (2019), ela luta para alcançar à igualdade de direitos, ultrapassando a condição de raça, de género, de forma a construir um novo modelo civilizatório humano, fraterno e solidário.

Portanto, para Muntaz torna-se necessário redobrar os estudos, de forma a justificar a sua presença nesses lugares que "não a pertencem". Corroborando com Kristeva (1994), o objetivo profissional, intelectual ou afetivo que alguns imigrantes se dão nessa fuga desenfreada é um subterfúgio à condição de estranho, pois ao escolher um plano, o estrangeiro se propõe a uma trégua ou um domicílio. É este mecanismo que a personagem adota para poder se manter firme.

Para além da situação de Muntaz, existe ainda uma outra categoria de imigrantes nacionais, aqueles que embora tenham nascido na província onde se encontram ou pelo menos na região sul, centro ou norte, o que os torna imigrantes é a sua condição social. Logo, pensaremos no imigrante nacional a partir de três vieses: primeiro aquele que se desloca de uma província à outra, em seguida aquele que não usufrui da equidade do gênero, e por último todo aquele que se encontra na classe social baixa. Desta forma, imigrantes nacionais correspondem as personagens deslocadas e periféricas que são marginalizadas pela sociedade que Ihes pariu e as devia acolher, pelo contrário tudo que encontram, é o desprezo, a indiferença, e outras vezes a morte.

É mister lembrar que o processo de colonização doutrinou nas diferentes sociedades, que todo aquele que vem é iníquo, pretende saquear, matar e destruir. Por conta disso, o termo viente se torna depreciativo e ofensivo para quem assim é denominado. Daí, advém que o imigrante nacional é muitas vezes atacado antes mesmo de mostrar a sua identidade e provar que também é nativo dessa região ou país.

$\mathrm{Na}$ sociedade moçambicana pouco se fale do impacto da guerra civil e pouco também se fala da relação que esta sociedade desenvolveu com os imigrantes nacionais ou não. Entretanto, a literatura cedeu um espaço pra tais reflexões, em que encontramos na escrita de diversos autores, personagens que têm um passado em comum e ainda que seja como subtexto, o trauma dessas guerras está patente. Momplé em Neighbours ou Nos Olhos da Cobra Verde, Luís Bernardo Honwana em Nós Matamos o Cão Tinhoso, procuram de uma forma irônica satirizar o mundo onde vivem. Lina Magaia em Deletha, José Craveirinha em Karingana ua Karingana, tal como tantos outros, falam da violência do sistema 


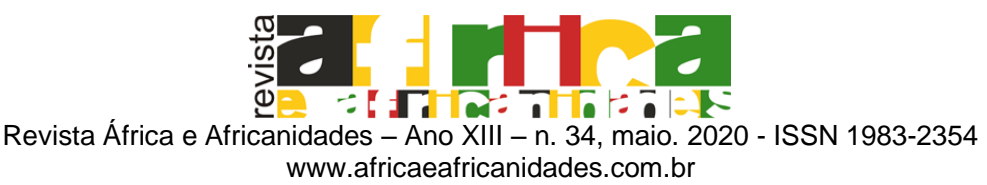

colonial, da barbárie que foi a guerra civil, mais do que isso, fazem alusão a brutalidade que o homem enquanto sujeito singular incide sobre outro homem igual a si mesmo, vejamos:

Suam no trabalho as curvadas bestas/ E não são bestas/ São homens, Maria!

Corre-se a pontapés na fome dos ossos/ E não são cães/ São seres humanos, Maria!

Ferras matavam velhos, mulheres e crianças/ E não são ferras, são homens.

Os velhos, as mulheres e crianças/ São os nossos pais /

Nossos irmãos e nossos filhos, Maria! (CRAVEIRINHA, 95, p.137)

A aversão que se tem da figura do imigrante e do imigrante nacional pode, de alguma forma ser explicada a partir dessa memória de guerra, herança da escravatura, do colonialismo, da guerra civil e da incursão do Apartheid no país. Onde o outro, o viente, são símbolos de ameaça, "aqueles que vêm para matar" ou para "me substituir", já que muitas vezes o imigrante visto como "o outro", é associado ao trabalho, afinal, não tem distracções ou raízes nessa terra nova. Estereótipo ou não, o imigrante representa força e fraqueza ao mesmo tempo, força por ter vindo e se dedicar ao trabalho com zelo, fraqueza por ter partido e abandonado os seus.

Esse enfrentamento entre o endêmico e o viente demonstra a necessidade de se pensar de forma ávida numa cultura de alteridade entre as humanidades. Em Neighbours, a autora nos convida a pensar nessa necessidade, não se dedicando a contar a história maior, ou seja, a história da guerra civil e do Apartheid, todavia, a história da experiência individual, relatando as mazelas dessa guerra para a multidão dos esquecidos, os imigrantes nacionais.

\section{A estranha vizinhança}

No entanto, o próprio bem-estar da África do Sul acabou por estar ligado à prosperidade de Moçambique e Angola. A África do Sul recebia água e electricidade das barragens moçambicanas e angolanas, necessitava de mão-de-obra moçambicana, obtinha o seu óleo combustível pesado de uma refinaria em Moçambique, e continuava a depender do porto de Maputo e da sua ligação ferroviária para servir o complexo industrial do Rand. Além disso, as empresas sul-africanas possuíam significativos investimentos que se viam ameaçados pela desestabilização. Nunca se chegou a saber como foi que os interesses económicos ou sequer os interesses políticos a longo prazo da África do sul foram servidos pela escalada da destruição que a desestabilização veio desencadear. Contudo não se duvida da responsabilidade da África do Sul na destruição causada aos seus vizinhos (NEWIT, 2012, p.482).

Nesta breve análise sobre o impacto do regime do Apartheid nos países vizinhos, Newit atenta para o fato de como a política de desestabilização debilitou 


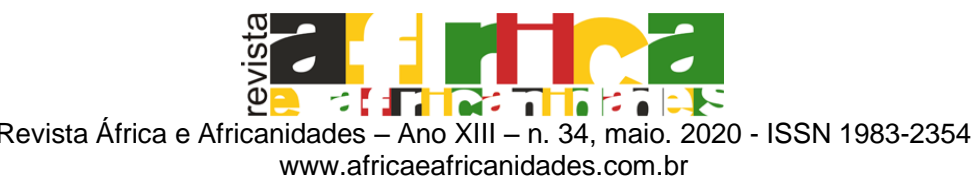

e arruinou grande parte da economia, não apenas em Moçambique, mas também em Angola. Assim, colocando em causa a economia de toda África Austral, Momplé no seu prefácio, igualmente chama atenção para essa estranha vizinhança:

Sempre me impressionou a permanente e trágica ingerência da minoria racista da África do Sul no meu país onde, sobretudo na década de oitenta incontáveis moçambicanos viram o rumo das suas vidas desviado ou simplesmente, deixaram de existir, por vontade e por ordem dos defensores do apartheid (MOMPLÉ,1995, p. 5).

Ainda no prefácio a autora esclarece que ao escolher o título Neighbours para o seu romance, pretendia referir-se a sinistra vizinhança do Apartheid. Contudo, é possível ponderar a reflexão em torno do título, pensando na relação da sinistra vizinhança dos vizinhos, ou seja, Narguiss perde a vida porque de todos os vizinhos é a única que se enche de curiosidade, coragem e reage ao assassinato de Leia e Januário, clamando aos gritos por socorro, como relata o narrador:

$\mathrm{Na}$ varanda do primeiro andar, mesmo em frente, o casal que lá vive e que ela conhece apenas de vista, desfaz-se em gritos. Ela grita apenas por socorro e ele, embrulhado no que the parece um lençol, repete qualquer coisa que Narguiss não consegue compreender. De vez em quando, grita também por socorro. Apesar da escuridão da noite sem lua e da acácia rubra que os oculta um pouco, Narguiss consegue vê-los agora, perfeitamente, iluminados por holofotes manejados na rua. $O$ homem continua a bradar qualquer coisa incompreensível e a mulher não para de pedir socorro. De repente, põem-se a correr de um lado para o outro, na exígua varanda, numa dança macabra. Narguiss não sabe se as balas que os atingem vêm de dentro da casa ou dos homens dos holofotes que também disparam sem cessar. Mas quando os vê cair, desata ela a gritar. Não vê o homem que, da rua, lhe aponta a arma pois toda a sua atenção está centrada na varanda da Flat em frente. As balas atingem-na, certeiras no pescoço e no peito... (MOMPLÉ, 1995, p. 94).

A cena acima descrita pode se considerar uma metáfora para a sociedade moçambicana que frequentemente se mantém impávida diante das atrocidades, reflete também essa estranha vizinhança que diante de gritos de socorro, escolhe silenciar-se. O silêncio dos vizinhos perante o assassinato de Leia, Januário e Narguiss, revela apatia e embrutecimento causados pelo regime do colonialismo e da guerra civil, na qual a dor, a fome, a destruição, o grito, o sofrimento e a morte, tornaram-se realidades próximas.

Neighbours é também um convite a pensar sobre os valores dessa sociedade que se estava a formar após a independência de Moçambique. Pensar nas relações de vizinhança que estavam sendo construídas, diferentes do que eram os hábitos e costumes mais antigos, em que os vizinhos eram tratados como se da mesma família pertencessem. Havia uma ideia clara por parte dos vizinhos, da importância do outro para o seu bem estar e da construção de toda uma 


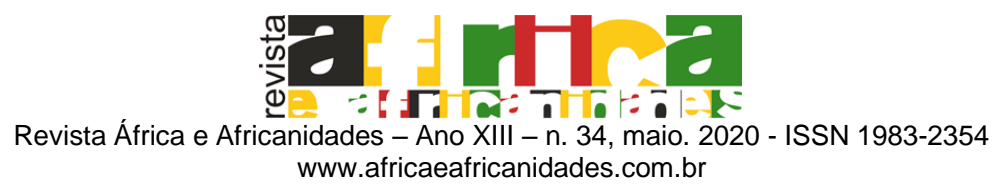

comunidade. A falta dessa consciência, denominaremos defeito de alteridade 5 . Formou-se então uma sociedade individualista e capitalista, onde reina a ausência de amor e a vida humana não tem mais valor.

Como afirma Newit (2012), um dos principais objetivos do Apartheid foi impedir a SADCC ${ }^{6}$ de se tornar uma força econômica na região, por conseguinte os caminhos-de-ferro e portos que uniam os países da SADCC ao mundo exterior e não se encontravam sob o controle Sul-africano foram desactivados. Sendo assim, os caminhos-de-ferro da Beira e o Lobito foram destruídos por sabotagem no início de 1980, tornando esses países dependentes dos caminhos-de-ferro e portos sul-africanos. Por outro lado, pretendia-se também a destruição das bases externas do $\mathrm{ANC}^{7}$ e da SWAPO, e o enfraquecimento político e econômico dos países vizinhos para que não pudessem agir de uma forma eficaz e preparada contra a África do Sul. Uma outra forma de efetivar essas ações, foram os assassinatos em massa de moçambicanos inocentes:

O raid em que Rui vai participar esta madrugada é, comparativamente a outros anteriores, coisa de pouca monta. Trata-se de assinar um casal que vive numa flat ao lado de uma outra ocupada por elementos do ANC. Propositadamente, deverá parecer que os atacantes tenham confundido o alvo da sua acção, pois o objectivo da missão é provocar a insegurança e o pânico entre a população e, ao mesmo tempo, a revolta contra 0 governo moçambicano por apoiar o ANC (MOMPLÉ, 1995, p. 96).

\section{O imigrante nacional e a memória}

A partir deste ponto, em que a memória da vizinhança, da boa vizinhança está destruída, os vizinhos em Neighbours tornam-se todos estranhos. Estamos diante de uma sociedade onde os habitantes sentem-se imigrantes nacionais, pois, temem estar no seu próprio habitat. Vivem inseguros, como se esse lugar não mais os pertencesse, visto que não tem domínio sobre ele: "Estão, no entanto todos de acordo sobre um ponto. 'O governo deve mandar embora esses do ANC. Ou então que Ihes arranje um lugar isolado para ficarem, pois é muito perigoso morar perto deles"' (MOMPLÉ, 1994, p.102).

A partir dessa fala do narrador é evidente que existe uma triste consciência de que a qualquer momento, por razões claras ou não, estes cidadãos podem ser alvejados dentro de suas próprias casas, reconhecem que não são mais senhores do seu destino e como solução sugerem o afastamento de todo aquele que lhes é estranho, pois o diferente é sinal de perigo. Torna-se necessário como vimos na fala a cima, afastar de uma vez por todas os membros do ANC e vale cogitar, que também todos aqueles que se mostrem diferentes. Como já foi dito, por intermédio

\footnotetext{
${ }^{5}$ Defeito de alteridade: conceito que estou desenvolvendo na minha tese, a partir da ideia de deformidade emocional causada pela dificuldade de conviver com o outro.
}

${ }^{6}$ Southern African Develpoment and Coordination conference

${ }^{7}$ African Nacional Congress 


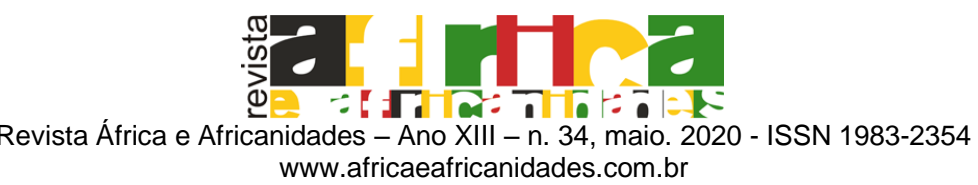

dos vientes os fantasmas do colonialismo renascem e os da guerra civil ganham corpos e nomes.

Corroborando com Newit (2012), a SADF8 desprendeu uma série de ataques diretos a países vizinhos, visando, ao que se parecia, bases do ANC, mas obtendo, na verdade, ascendência psicológica demonstrando a impunidade com que a África do Sul podia atacar os estados independentes. Como aponta o narrador de Neighbours nota-se que a dado momento, por via dos investimentos do Apartheid em Moçambique, todo aquele que pertencia a ANC era tido por uma parte da sociedade (pouco informada) como inimigo, pois a sua presença representava ameaça, o que demonstra por um lado, que a política de destabilização da África do Sul estava a surtir efeitos em Moçambique, não apenas amedrontado um conjunto de moçambicanos que a partir daí se sentem estrangeiros na sua terra, desprotegidos, e como também permitiram o desenvolvimento de sentimentos de aversão e ódio pelo outro, ódio ainda patente de alguma forma na sociedade atual. Para desenvolver esse tema cabe um outro estudo.

Já no ano de 1995 Glissant afirmou que se a ANC e Nelson Mandela não conseguissem que a população sul-africana composta por zulos, negros, mestiços, indianos, e brancos vivessem todos juntos, algo do séc. XXI, do nosso devir, do futuro das humanidades que representamos estaria profundamente ameaçado e perdido. Glissant (1995) compreendeu que objetivo primeiro de Mandela era se não, sair da identidade raiz única e investir na crioulização do mundo e é por esse viés que se atenta este estudo.

A crioulização do mundo termo cunhado em Glissant baseia-se na seguinte tese:

O mundo se criouliza. Isto é: Hoje, as culturas do mundo colocadas em contacto umas com as outras de maneira fulminante e absolutamente consciente transformam-se, permutando entre si, através de avanços de consciência e de esperança que nos permitem dizer - sem ser utópicos e mesmo sendo-o- que as humanidades de hoje estão abandonando dificilmente algo em que se obstinavam há muito tempo - a crença de que de que a identidade de um ser só é valida e reconhecível se for exclusiva, diferente da identidade de todos os outros seres possíveis. E é essa mutação dolorosa do pensamento humano que eu gostaria de cantar com os senhores (GLISSANT, 2012, p.10).

Como se pode observar, este é um fenômeno que se dá naturalmente desde os primórdios da humanidade ainda que com relutância, conscientemente ou não, sempre se deu esse processo e o com advento do pós-nacionalismo, a crioulização do mundo se vem edificando de forma célere. Portanto, torna-se necessário que as humanidades aceitem de uma vez por todas que não existe mais um eu-singular, mas sim, um eu-plural feito das inúmeras e construtivas experiências e trocas que se oferecem entre as diferentes culturas.

${ }^{8}$ SADF- South African Defence Force 


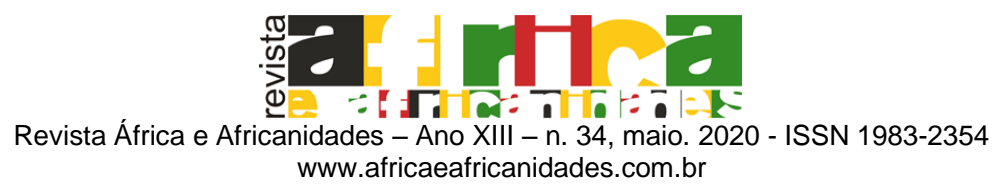

Logo, se compreendermos que o que motiva as guerras e os conflitos humanos é de alguma forma o defeito de alteridade, a inaceitação do outro em quanto ser humano, pensante e senhor do seu destino, concordaremos que uma das formas da crioulização do mundo é também a equidade de gênero, um mundo que não seja apenas masculino, mas também feminino, abrindo-se desta maneira para outras possibilidades de governação.

Percebe-se também em Neighbours, que em 1992 altura em que se passa o enredo do romance perpetua-se ainda a memória do colonialismo que como vimos, coloca Muntaz numa situação de imigrante e ameaça para os outros colegas e professores para quem precisa provar que merece aquela vaga. Igualmente, notamos uma memória machista por parte de sua família e da sociedade:

Mas para a desolação da mãe, a rapariga nem quer ouvir falar de casamento, dedicando-se aos estudos de uma maneira que toda a família considera muito pouco feminina. Aliás, quando concluiu a nona classe Muntaz muito lutou contra a oposição dos Pais para estudar para além dos limites tidos, no seu meio, como normais. "Estudar tanto para quê? Mulher não é para encher cabeça" (MOMPLÉ, 1995, p.14).

Pode se observar que há aqui uma certa violência instalada pela família, que pelo fato de ser mulher, a considera incapaz de progredir nos estudos e também desnecessário prolongá-los. Fato que se repete nas personagens imigrantes de Rawet (1998), em que a família que deveria ser o lugar de alento é pelo contrário, seu alquebramento. Tanto em Rawet como em Momplé deparamonos com personagens que estão no limite, os imigrantes nacionais e domésticos, que são primeiramente imigrantes no seio de suas próprias famílias. Consequentemente, encontram no silêncio sua terapia e forma de resistir. $O$ silêncio de Muntaz, que durante o texto nunca se refere aos seus estudos, ou das personagens raweianas, demonstra como o afastamento, indiferença, são traços dessas memórias ainda magoadas, de corpos sofridos com as guerras.

Ainda assim, corroborando com Patricia Collins (2019), o silêncio da mulher negra nem sempre deve ser visto como submissão, mas sim como resistência, pois existe um espaço privado e oculto na consciência dessas mulheres que durante muito tempo as permitiu resistir e transcender à interseccionalidade (opressões de raça, gênero, classe e sexualidade).

\section{O deslugar do imigrante nacional: Leia e Januário}

Faz-se importante ressaltar que o deslugar do imigrante em solo pátrio, refere-se há um movimento frequente e comum em qualquer sociedade e época, ou seja, como já se mencionou, trata-se daquele que pela condição de desterrado que lhe é atribuída, precisa provar para aos demais que merece estar naquele lugar, nessa "nova terra". 


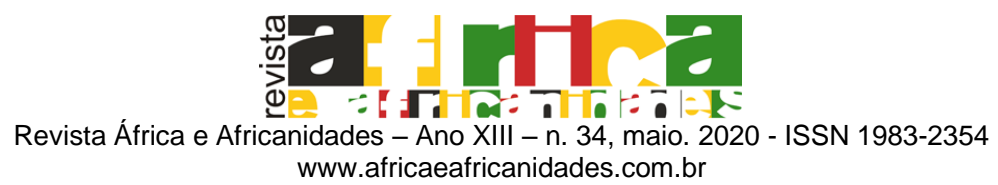

A personagem Januário representa as máscaras sociais, o homem personagem, que o ser humano precisa interpretar no seu dia-a-dia de maneira a sobreviver a realidade que the circunscreve. Januário é o menino da aldeia pobre, que quebra os paradigmas ao se aventurar numa viagem rumo a um futuro menos sombrio. É o órfão que perde os pais queimados vivos por homens armados e em silêncio continua a sua busca por um futuro melhor. Parafraseando Krsisteva (1994), o estrangeiro é aquele que perdeu a mãe, nada o retém e todos os sofrimentos, todos os insultos, todas as rejeições lhe são indiferentes na procura dessa terra prometida, desse país que não existe mais, que ele traz no seu sonho e que deve realmente ser chamado de um além. Não é gratuitamente que está personagem tem a sua aldeia destruída e os pais queimados vivos, Januário torna-se órfão triplamente, o que agrava a sua situação de imigrante nacional. Sem mãe, sem terra, pobre, o verdadeiro protótipo de imigrante nacional, o professor pobre que simboliza a classe dominada que na capital do país, não tem lugar.

No texto esse deslugar nos é exposto por viver numa casa emprestada, depois de já ter vivido de favor e humilhações na casa da sogra:

Para poderem ficar sozinhos no quarto que Leia, em solteira partilhava com as irmãs, antes de se empregar em Maputo, estas tinham que arrastar os colchões todas as noites e dormir na sala porque o quarto da mãe, demasiado acanhado, não podia albergar mais ninguém. Por vezes as raparigas resmungavam, mesmo diante de Januário, enquanto improvisavam leitos no chão. E de madrugada, quando o rapaz, pé ante pé, tinha que atravessar a sala para ir à casa de banho arranjar-se, antes de ir para o serviço, elas, se estavam acordadas, lançavam-lhe olhares desconfiados, ao mesmo tempo em que se apressavam a puxar os lençóis até ao pescoço (MOMPLÉ, 1995, p.17).

Esta personagem por sua vez, como apresenta o narrador: "Irritava-se profundamente com estas e outras atitudes das cunhadas pois nunca suportou relacionamentos dúbios e complicados. E essa irritação, que a falta de dinheiro agravava, reflectia-se no modo como falava ou no silêncio obstinado que desencorajava qualquer diálogo" (MOMPLÉ, 1995, p.18). O imigrante nacional aqui representado por Januário demonstra como este grupo, corroborando com Kristeva (1994), transformaram os seus inquietamentos em focos de resistência, pois se escolhesse ficar em casa, talvez seria denominado marginal, um doente ou fora -da- lei, sem lar. Pelo contrário, tornando-se uma personagem, multiplica as máscaras, jamais é inteiramente verdadeiro ou inteiramente falso, pois sabe-se adaptar aos afetos e desafetos, as antenas superficiais de um coração de basalto.

É deste modo, sobre o horror dos jovens, funcionários públicos que autora de Neighbours nos instiga a pensar e questionar a vida destes imigrantes nacionais que colocados à margem das políticas públicas, sofrem com a falta de habitação. O imigrante nacional não possui direitos políticos pois, lhe é negado o direito a propriedade imobiliária o que pode ser observado no romance a partir da dificuldade que Leia e Januário encontram para arrendar uma casa e acabam morrendo numa casa emprestada. O casal reflete a vida dos homens máquinas, 


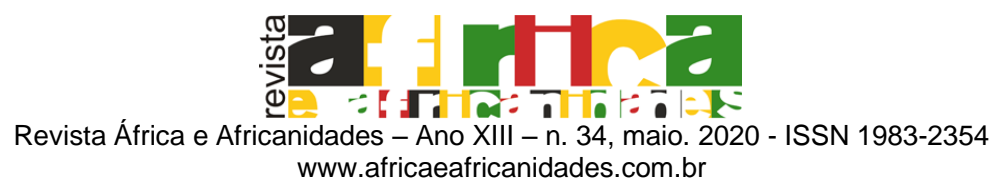

que após o trabalho não constituem objeto de apreensão para o governo, desde que se apresentem no dia seguinte a tempo a hora gerando riquezas para as classes dominantes, que se mostram totalmente indiferentes a essas realidades. Indiferentes a essa estrutura financeira, que é o trabalhador, aquele que também produziu capital para financiarem a guerra civil.

Através de Leia, outra imigrante nacional, Momplé continua a saga do deslugar, se não vejamos:

Em casa da mãe, havia momentos que que the parecia sufocar entre as insinuações das irmãs (que homem é este que nem consegue alugar casa...) e os rompantes e silêncios do marido. Nem mesmo o nascimento da pequena íris logrou melhorar o ambiente tenso em que viviam. Em certa medida veio até agravá-lo porque era mais uma boca para alimentar, com produtos só encontráveis na candoga ou na interfranca (MOMPLÉ,1995, p.20).

Assim como em Judith de Rawet (1998), Leia encontra o desamparo no seio da família e o fato de ter uma filha com um imigrante nacional, só vai agravar a sua situação. É nessa direção, que a personagem pensa na prostituição como possível solução:

Por um instante, Leia esteve tentada a ceder. Sentia-se tão cansada de procurar resolver uma situação que se arrastava há anos e vinha minando a sua vida. Sabia de algumas colegas que, para poderem alimentar os filhos, se entregavam regularmente a qualquer homem que Ihes desse dinheiro. Porque não ela, para conseguir um tecto onde viver com o marido e a filha? Não perderia nenhum pedaço...( MOMPLÉ, 1995, p.20).

A situação de Leia parece antever o lugar escuro do deslugar, onde o cidadão sem lar, que não tem mais esperança torna-se estranho para ele mesmo ao perceber que mais alguém habita nesse corpo, que à medida que passa vai se tornando estranho, pois não tem lugar onde descansar. Parece que a personagem fica numa situação de perda de identidade, e questiona sobre o seu próprio ser, "Eu faço o que se quer, mas não sou "eu"- meu "eu" está em outro lugar, meu "eu" não pertence a ninguém, meu "eu" não pertence a "mim"... "eu" existe?" (KRISTEVA, 1994, p.16). O imigrante nacional sente-se estrangeiro para ele mesmo e o seu corpo começa a assumir outras funções e adquirir novos significados que trespassam o conhecimento primeiro que ele tinha sobre si. $O$ não ter lugar obriga-o a colocar-se nos lugares que ninguém quer estar, como o subemprego, a prostituição e tantos outros.

Quando o casal Leia e Januário são assinados, desperta atenção o fato de se saber que ela estava grávida, nota-se aí mais uma metáfora, se pensarmos na gravidez como sinal de esperança. $O$ imigrante nacional, espera que algo de bom aconteça, espera conseguir um lugar para habitar e uma identidade. Por ironia do destino ou da autora, como preferirmos, o casal é assassinado aos olhos da filha (Íris), por membros do Apartheid, na casa emprestada em que vivem. 


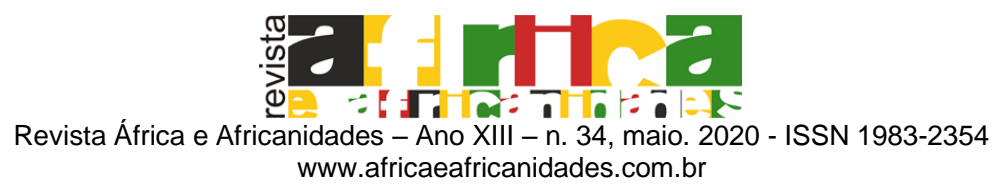

Percebemos que Íris, para além daquela que vê, nome de origem grega que significa "mensageira pela palavra", assim como Januário se torna duplamente órfã. Órfã de pais e órfã de lugar. É mais uma abandonada em terra alheia, sem voz, sem palavra, não pode cumprir a função do seu nome, não apenas por se tratar de uma criança, como também, por assumir desta forma o lugar de imigrante nacional, Íris é mais uma personagem emudecida pelas guerras.

A morte deste casal, choca, a medida que Januário para evitar tal sorte titubeai algumas palavras em inglês que mal domina, apelando pela vida ou quiçá reivindicando tal direito. Talvez seja esse o modus vivendi do imigrante nacional, tatear no desconhecido, em busca de sobrevivência.

Está cena é um convite a refletir sobre o esforço que o cidadão nacional faz para viver no seus próprio país em detrimento de um estrangeiro, que chega e tem a vida toda facilitada "até pra matar". Leia e Januário fazem parte de uma classe minúscula, simples vítimas do sistema ou da guerra, personagens liliputianas que não acrescentam grande coisa na sociedade e desaparecem no silêncio do tempo. São os miseráveis marginais, que ninguém sentira falta, nem tão pouco os seus familiares, são aqueles que acreditaram que migrando teriam melhores oportunidades de vida e com a morte descobrem:

O capitalismo cria a ilusão de que as oportunidades são iguais para todos, a ilusão de que triunfam os melhores, os mais trabalhadores, os mais diligentes, os mais "económicos ". Mas, com a mercantilização da sociedade, cada um vale o que o mercado diz que vale. Não há nenhuma consideração pelas virtudes, que não sejam as "virtudes" exigidas pela concorrência: a ambição pela riqueza e a capacidade de transformar tudo, homens e coisas, em objecto do cálculo em proveito próprio. (MELLO e NOVAIS, 1998, p.581)

Narguiss tem ao menos uma família, esposo e filhas que chorarão ou se alegrarão com a sua morte. Mas a morte de Januário e Leia, funcionários exemplares, homem e mulher trabalhadores, o que despertarão para além de indiferença? Ambos simbolizam as vítimas anônimas do capitalismo que desparecem anonimamente.

\section{O lugar do imigrante: Dupont}

Virgílio Dupont é filho de mauricianos e nasceu em Xinavane para onde os pais imigraram ainda jovens. É também o último de cinco irmãos, o que, de certo modo, Ihe justifica o carácter tíbio pois cresceu entre a obsessiva protecção da mãe e o desencantado desprendimento do pai. Tibieza que o torna incapaz de realizar qualquer esforço prolongado e o levou a desistir de estudar antes de concluir o concurso comercial e a ser ainda hoje, um profissional medíocre (MOMPLÉ,1994, p.45).

A personagem Dupont, descendente de mauricianos torna-se imigrante de terra e de família, pois desafia as convicções familiares e sociais e casa-se com 


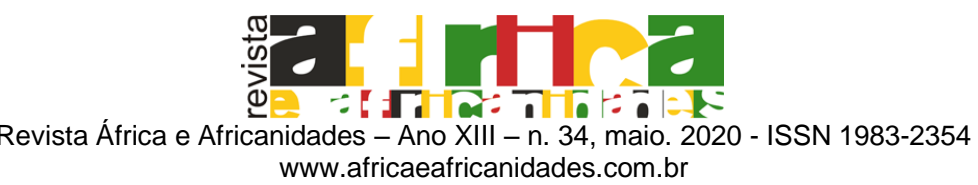

uma mulata, pela qual sente apenas atração sexual. Dupont é sinônimo de afastamento, um homem indiferente a tudo e todos, afinal, "a indiferença é a carapaça do estrangeiro: insensível, distante, no fundo, ele parece fora do alcance das agressões que, contudo, sente com a vulnerabilidade de uma medusa" (KRISTEVA, 1994, p.15).

Esta personagem representa aqueles que distantes de suas origens não pertencem a nenhum lugar, nenhum tempo e nenhum amor. Ainda que um profissional medíocre como aponta o narrador, o imigrante branco em Neighbours ou na sociedade moçambicana, ocupa um lugar de prestígio social, adquirido automaticamente pela condição da sua raça, que ele e tantos outros acreditam ser superior aos demais, herança do colonialismo em África.

Com a invenção da raça o Homem branco foi sempre colocado num pedestal, independentemente das atrocidades que cometia, a colonização fez com que mesmo após a independência e nos dias que correm, o estrangeiro, principalmente branco, continue ocupando lugares de privilégio no seio da sociedade moçambicana onde é tratado de forma particular. Por outro lado, como já foi aqui abordado o poderio econômico acrescenta mais um degrau a condição de imigrante, seja ele nacional ou estrangeiro, o que se pode observar na fala de Dupont, que considera por sua vez os sul-africanos superiores a ele: "Tem que correr tudo bem. É gente fina, sul-africanos brancos. Por isso vê lá o que fazes" (MOMPLÉ, 1995, p.24).

De uma forma banal, Momplé chama atenção para o lugar de privilégio que este grupo de imigrantes sul-africanos assassinos ocupava e o total descaso e abuso que tinham por toda uma sociedade, como se pode ver na fala seguinte: "... Os homens estão na sala e, enquanto não chega o cheé para rezar as orações, comentam o crime. Consideram muito intrigante o facto de os assassinos terem vindo com holofotes, num claro desprezo pela Segurança deste país" (MOMPLÉ, 1994, p.101). Podemos a partir daqui pensar na necessidade de se intensificar as abordagens decolonias, de forma a desconstruir essa ideia do Homem branco versus poder, pois pode-se cogitar, que a facilidade com que os homens do Apartheid se implantaram dentro do espaço moçambicano, fizeram aliados e, desestabilizaram essa sociedade tem que ver também com o "poderio racial".

Outro aspecto que cabe ressaltar é a dualidade que esta figura do Homem branco e imigrante carrega, aquele que é amado e odiado ao mesmo, aquele, que assim como o imigrante nacional, transmite insegurança e suspeita no meio que se insere, se não vejamos:

Será que estou realmente em casa? Será que sou eu ou serão eles senhores do "futuro"? Esse hábito da suspeita provoca reflexão em alguns, quase nunca humildade e nunca mesmo generosidade. Mas também suscita em outros a raiva regressiva e proteccionista: não será preciso permanecermos unidos para, juntos, expulsarmos o intruso ou, pelo menos, coloca-lo no "seu" lugar? "O senhor" transforma-se então em escravo, perseguindo o seu conquistador. Pois o estrangeiro, perseguido como um invasor, desperta no nativo uma paixão sepulta: a de matar 0 


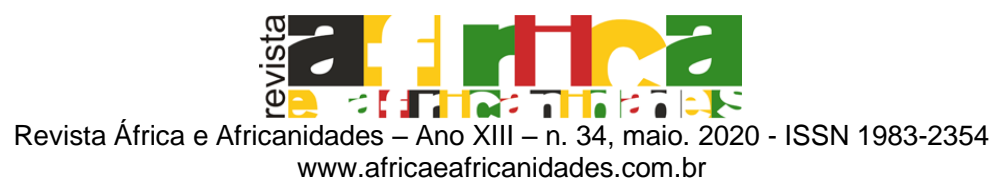

outro, inicialmente temido ou desprezado, depois promovido da categoria de dejeto ao estatuto de perseguidor poderoso, contra o qual um "nós" se solidifica para se vingar (KRISTEVA, 1994, p.27).

Enquanto esperam pelo momento do assassinato na casa Dupont, observamos como Romualdo o trata na sua própria casa, com despeito e arrogância, não apenas pelo status que possui, já que foi ele quem convidou ou contratou Dupont para se ajuntar a eles, nessa "missão de serviço", como eles mesmos apelidam. Como também pelo fato da presença de Dupont enquanto imigrante suscitar nele uma raiva regressiva e proteccionista, que lhe dá o direito de pensar que este não merece ter uma mulher como Mena, pelo simples fato de ser estrangeiro:

"Se eu te apanhasse, mostrava-te o que é um homem", pensa ele, "mal empregada para o cagarola do teu mauriciano. Está tão nervoso o gajo que só está bem a saltitar como um gafanhoto ...E uma mulher destas nas mãos de um merdas"( MOMPLÉ, 1994, p.22).

Importa referir que ao pensar no lugar do imigrante no romance de Momplé, não se pretende de forma alguma reproduzir mensagens xenófobas, mas pelo contrário convidar a refletir sobre o defeito de alteridade, que motivou e motiva seres humanos a envolverem-se nas mais fatídicas guerras apoiadas pela defesa de uma identidade. De outro modo, propõe-se a pensar numa cultura mestiza, numa cultura que engloba em vez de excluir, pois, "em unas pocas centúrias, o futuro pertencerá à mestiza. Porque o futuro depende da quebra de paradigmas, depende da combinação de duas ou mais culturas. Criando um novo mythos - ou seja, uma mudança na forma como percebemos a realidade, na forma como nos vemos e nas formas como nos comportamos -, la mestiza cria uma nova consciência" (GLORIA ANZALDÚA, 2019. 326).

Desta forma, parafraseando Glissant (2005), no encontro entre as culturas do mundo, precisamos ter a força imaginária de conceber todas as culturas como agentes de unidade e diversidade libertadoras, em simultâneo. Permitir-lhes que usufruam do direito à opacidade, não precisando mais "compreender" o outro, ou seja, reduzi-lo ao modelo da nossa própria transparência, para viver com esse outro ou construir com ele. "Nos dias de hoje, o direito à opacidade seria o indício mais evidente da não barbárie" (GLISSAN, 2005, p.86).

\section{Conclusões}

Inconformada com a guerra civil e o incessante apoio do regime do Apartheid, Momplé procurou representar os mais desfavorecidos socialmente e politicamente, incluindo as próprias vítimas de guerra, que em fuga das suas zonas de origem ou, simplesmente a procura de melhores condições de vida, encontram na capital do país aquilo que mais temiam, a morte.

E é nessa busca por melhores condições de vida que as personagens de Neighbours, simples imigrantes e imigrantes nacionais aqui caracterizadas em três 


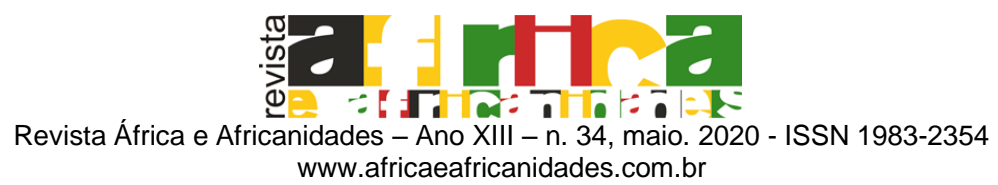

categorias: os que deixam suas terras de origem, os miseráveis e, os que não têm acesso à equidade, apercebem-se durante o seu percurso que fazem parte de uma "humanidade liquida":

Já não há trabalhadores propiamente ditos. Só existem nómades no trabalho. Se, ontem, o drama do sujeito era ser explorado pelo capital, a tragédia da multidão hoje é já não poder ser explorada de modo nenhum, é ser relegada a uma "humanidade supérflua", entregue ao abandono, sem qualquer utilidade para o funcionamento do capital (MBEMBE, 2012, p.15-16).

Januário, Leia, Dupont, Narguiss, Muntaz, movidos pelo desejo de conseguir um trabalho condigno e poderem ser donos dos seus destinos, descobrem que vivem numa nova era, a era da "humanidade supérflua", em que suas vidas e desejos igualam-se a nada. Vítimas do Apartheid, escolhidos aleatoriamente para morrer, o que espelha a sua dispensabilidade, dão voz as minorias sociais, as figuras sem voz e marginalizadas que, como aponta 0 narrador passam despercebidas na sociedade moçambicana "o noticiário, porém, prossegue sem uma palavra sobre qualquer crime na avenida Emília Daùsse" (MOMPLÉ, 1994,p.102-103).

Através desta discussão, volvidos vinte e sete anos do fim da guerra civil em Moçambique, percebe-se que como afirmam Waldan (2012) e Grützmacher (2006), que a medida que o tempo passa, as formas de participação nos conflitos tornam-se apenas memória, inscrevendo-se num terreno movediço em que a guerra muda de lugar e com ela, o olhar que a interroga e a recria, portanto, ao referir-se ao novo romance histórico não se trata mais de procurar a representação fidedigna de uma época histórica.

É nesta senda que a partir de Neighbours propõe-se diferentes leituras da realidade, conferindo deste modo ao romance de Momplé o mesmo estado cognitivo que o da obra historiográfica, pois através do primeiro se pode revisar a história. Desta forma, faz-se um apelo ao enfrentamento do defeito de alteridade de modo, não a fazer um convite a fraternidade entre os povos como bem coloca Kristeva, mas um apelo a opacidade como propõe Glissant. É necessário que as humanidades, a partir das suas inúmeras experiencias de guerra, reflitam agora na desnecessidade de coisificar o imigrante nacional e o simples imigrante.

Que possamos interpretar o outro a partir de nós mesmos afinal, somos todos estrangeiros em nos mesmos, a medida que não conseguimos compreender certas atitudes que julgávamos ser apenas do outro, outro sim, em algum momento seremos estrangeiros para alguém, em algum lugar. Portanto, é imprescindível reconhecermos a angustiada estranheza em conviver e aceitar o outro, pois é por essa via que nos abrimos para deixar de pensar na identidade como raiz única e intransigente e daí contribuímos para o cessar das guerras onde vivemos e além-fronteiras.

Penso que chegamos a um momento da vida das humanidades em que 0 ser humano começa a aceitar a ideia de que ele mesmo está em perpétuo processo. Ele não é ser, mas sendo e que como todo sendo, 


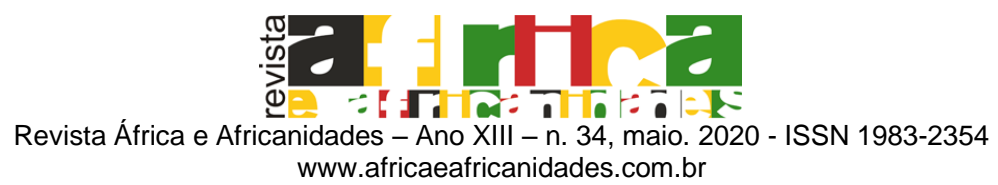

muda. Penso que está é uma das grandes permutações intelectuais, espirituais e mentais da nossa época que dá medo a todos nós, todos temos medo desta ideia. Um dia vamos admitir que não somos uma entidade absoluta, mas sim um sendo mutável (GLISSANT,2005, p.33).

Já se faz tarde e é preciso que as humanidades enfrentem o medo e aceitem conscientemente que não somos mais uma identidade absoluta, que através de todos os movimentos de ressignificação das humanidades (escravatura, patriarcado, capitalismos, modernidade, globalização, etc.) estamos sempre nos adaptando, metamorfoseando, movendo e reconstruindo uma identidade, que não é mais una, mas várias numa só, pois o mundo criouliza-se todos os dias. O desafio agora não é integrar o outro, ou fingir nomenclaturas que o incluam dentro de nós, o desafio é respeitar a sua condição de outro, e ter consciência, que somos todos outros para outros.

\section{REFERÊNCIAS}

ANZALDÚA, Gloria. La conciencia de la mestiza / Rumo a uma nova consciência. In: HOLLANDA, Heloisa B. de (Org.). Pensamento feminista. Conceitos fundamentais. Rio de Janeiro: Bazar do tempo: 2019, pp. 323-339.

ARISTÓTELES. Poética. Tradução de Ana Maria Vlente. Lisboa: Fundação Calouste Gulbenkeian, 2008.

CARNEIRO, Sueli. Enegrecer o feminismo: a situação da mulher negra na América Latina a partir de uma perspectiva de género. In: HOLLANDA, Heloisa B. de (Org.). Pensamento feminista. Conceitos fundamentais. Rio de Janeiro: Bazar do tempo: 2019, pp. 313-321.

COLLINS, Patricia H. Pensamento feminista negro: o poder da autodefinição. In: HOLLANDA, Helloisa B. de (org.) Pensamento feminista. Conceitos fundamentais. Rio de Janeiro, Bazar do Tempo, 2019, pp. 271-310.

CRAVEIRINHA, José. Karingana ua Karingana. Maputo: Associação dos escritores Moçambicanos, 1995.

GLISSANT, Édouard. Introdução a uma poética da diversidade. Tradução de Enilce do Carmo Albergaria Rocha. Juiz de fora: Editora UFJF, 2005.

GRÜTZMACHER, Lukasz. Las trampas del concepto "la nueva novela histórica" y de la retórica de la historia postoficial. Acta Poetica 27 (1): PRIMAVERA, pp. 141-167, 2006. https://revistas-filologicas.unam.mx/acta-poetica/index.php/ap/article/view/193

HONWANA, Luís Bernardo. Nós matámos o Cão-Tinhoso. Lisboa: Afrontamento, 2000.

KRISTEVA, Julia. Estrangeiros para nós mesmos. Tradução Maria Carlota Carvalho Gomes. Rio de Janeiro: Rocco,1994.

MAGAIA, Lina. Deletha Pulos na Vida. Maputo: Editorial Viver, 1994.

MBEMBE, Achile. Crítica da Razão negra. Tradução de Sebastião Nascimento. Brasil: n1 edições, 2018.

MELLO, João Manuel Cardoso de e NOVAIS, Fernando A. Capitalismo tardio e sociabilidade moderna. In: SCHWARCZ, Lilia Moritz (Org). História da vida privada no 


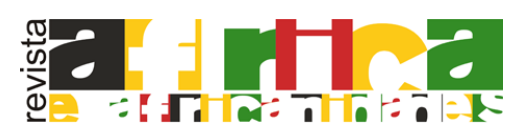

Revista África e Africanidades - Ano XIII - n. 34, maio. 2020 - ISSN 1983-2354

www.africaeafricanidades.com.br

Brasil- Contrastes da intimidade contemporânea. São Paulo: Companhia das letras, 1998, pp. 560-658.

MOMPLÉ, Lília. Neighbours. Maputo: Associação dos escritores moçambicanos, 1994.

MOMPLÉ, Lília. Os olhos da cobra Verde. Maputo: Associação dos escritores moçambicanos, 1997.

NEWIT, Malyn. História de Moçambique. Tradução de Lucília Rodrigues e Maria Georgina Segurado. Portugal: Publicações Europa- América, 2012.

RAWET, Samuel. Contos de Imigrante. Rio de Janeiro: Ediouro, 1998.

WALDMAN, Berta. Caminhos cruzados: a segunda guerra mundial em dois tempos. In Visões de guerra: Lasar Segal. São Paulo: imprensa Oficial do Estado de São Paulo: Museu Lasar Segal: Centro de Cultura judaica, 2012, pp.123-131. 